\title{
Effects of Statin and Aerobic Physical Exercise Association in the Cardiomyocytes of the Rat. Morphometric Study
}

\author{
Efectos de la Asociación de Estatina y del Ejercicio Aeróbico en los Cardiomiocitos de Rata. \\ Estudio Morfométrico
}

\begin{abstract}
*,** Susimary Aparecida Trevizan Padulla; ${ }^{* * *}$ Reinaldo Azoubel; ${ }^{* * * * * *}$ Mariana Rotta Bonfim; ** Marilita Falângola Accioly; *José Carlos Silva Camargo Filho; ${ }^{* * *}$ João Armando Padovani; ${ }^{* * *}$ Antônio Carlos Brandão \& *** Dorotéia Rossi Silva Souza
\end{abstract}

PADUlla, T. S. A.; AZOUBEL, R.; BONFIM, R. M.; ACCIOLY, F. M.; CAMARGO FILHO, S. J. C.; PADOVANI, J. A.; BRANDÃO, A. C. \& SOUZA, S. D. R. Effects of statin and aerobic physical exercise association in the cardiomyocites of the rat. Morphometric study. Int. J. Morphol., 27(1):83-88, 2009.

SUMMARY: Physical exercise and statins, recommended interventions to dyslipidaemia treatment, are independently related to cardiomyocytes alterations, characterized by miocardic hypertrophy and apoptosis, respectively. Thus, the objective of the present study was to analyze the effects of statin and aerobic physical exercise association in the morphometric parameters of cardiac cell nucleus. 40 male rats adults were divided into four groups: exercised (DE); sedentary (DS), exercised and statin use (DES); sedentary and statin use (DSS). The animals received during the whole experimental period a hiperlipidic diet added $20 \%$ of coconut oil and $1.25 \%$ of cholesterol; after 30 days of its ingestion, a blood collection was made to verify the dyslipidaemia. Simvastatin (20 mg) was taken five days a week, during eight weeks. During this period, the animals exercised 60 minutes daily in the treadmill. After the last day of the protocol, the cardiac muscle was collected and maintained in liquid nitrogen $\left(-180^{\circ} \mathrm{C}\right)$; the cuts were stained by Hematoxilin-Eosin method, and the cardiac fibers were submitted to the nuclear morphometric analyses. The data were analyzed using descriptive analyses, paired $\mathrm{T}$ test, Kruskal-Wallis test and Dunn post hoc test; for all analyses, it was adopted $\mathrm{p}<0.05$. It was verified that the group receiving statin presented values statistically significant in comparison to the other groups, in the tridimensional and linear variables. The exercised and statin group, the values obtained in the morphometric analyses were similar to the control group. It is suggested that statins alone can cause alterations in the nucleus of cardiac cells that can be related to apoptosis occurrence and, when exercise is practiced associated to statin administration, the effects of statin can be reduced, what can be related to beneficial adaptations of cardiac mitochondrial in response to physical exercise, turning them more resistant to apoptotic stimuli.

KEY WORDS: Hydroxymethylglutaryl-CoA Reductase Inhibitors; Exercise; Cardiomyocite nuclei.

\section{INTRODUCTION}

Dyslipidaemia is characterized by lipidic metabolic alterations that include rise in triglycerides, total cholesterol, free fat acid, LDL-cholesterol, and reduction in HDL-cholesterol. This situation is considered as conventional risk factor to cardiovascular disease, being related to atherosclerose (Sociedade Brasileira de Cardiologia, 2007).

Due to the strong association between dyslipidaemia and coronary arterial disease, an intervention is necessary, aiming the lipidic profile adjustment and a better quality of life. In this way, the Brazilian Cardiology Society indicates as interventional and prevention methods for dyslipidaemia the life style change, that include food habits and aerobic physical activity practice, and also the use of hipolipidemic medications, being statins the most indicated.

Statins act inhibiting the HMG-CoA reductase enzyme, resulting in reduced cholesterol hepatic syntheses, what rises the syntheses of LDL receptors in the hepatocite surface and, consequently, LDL clearance is rised, what can also reduce its intraluminal absorption (Silva, 2002).

* Professor of the Physiotherapy Department - São Paulo State University - Brazil.

** Doctor Student of Medicine University of São José do Rio Preto - Brazil.

**** Professor of Medicine University of São José do Rio Preto - Brazil.

${ }^{* * *}$ Mestre Student of São Paulo State University - Brazil. 
Besides the effects on lipid profile, it has been reported that statin use is associated to the occurrence of benefic effects to the organism, known as pleiotropic effects, and occur independently to the reduction of blood lipids. Among them, it can be cited the endothelial function improvement, the plaque aggregation diminution, and also the remodel and regression of myocardial hypertrophy (Jasin'ska et al., 2007).

Similarly, physical activity practice is related to benefic alterations in the lipid profile and in the myocardial function of its practitioners. Studies demonstrate that physical activity subjects presents higher levels of HDL-Cholesterol and lower levels of triglycerides, LDL and VLDLcholesterol, compared to sedentary subjects, what can be related to a higher utilization of lipids as mainly energetic source to this activity (Cambri et al., 2006; Prado \& Dantas, 2002). Moreover, the duration and the frequency of physical exercises are related to the higher cardiac overload, what can promote excentric cardiac hypertrophy and a longitudinal growth of the myocyte (Evangelista et al., 2003).

Thus, due to the influence of statins and physical exercise in the cardiac musculature, it is relevant to verify the myocardial responses of its association. So, the objective of the present study was to analyze the effects of statins associated to aerobic physical exercise in the nuclear parameters of the myocardium fibers of dyslipidemic rats.

\section{MATERIAL AND METHOD}

Fourthy male adult wistar rats (Rattus norvegicus), weighting $308.4 \pm 44.63$ grams, were maintained in colective plastic cages with five animals, in local with controlled temperature and umidity $\left(22 \pm 2{ }^{\circ} \mathrm{C} ; 50 \pm 10 \%\right)$. The animals were aleatory divided into four groups of ten animals, being dyslipidemic sedentary (DS), dyslipidemic exercised (DE), dyslipidemic sedentary with statin (DSS) and dyslipidemic exercised with statin (DES).

All the adopted procedures were approved by the Ethics Research Committee of the Medicine University of São José do Rio Preto (FAMERP - Process number 5363/ 2005) and follow the Ethical Principles in the Animal Experimentation of the Brazilian College of the Animal Experimentation (COBEA).

Dyslipidemia was induced by a hyperlipidic diet based on a standard diet (AIN-93G), substituting the soy oil for $20 \%$ of coconut oil and adding $1.25 \%$ of cholesterol (Accioly, 2007); water and diet were offered ad libitum.
Blood analyses were done before and 30 days after the diet consumption to verify the dyslipidemia occurrence. Blood samples were obtained by cardiac punction method, being used to total cholesterol, triglycerides and HDLcholesterol dosage. To each collection it was respected 12 hrs of abstinence of food and $24 \mathrm{hrs}$ of resting.

The seric levels of TG and TC were determined by enzymatic calorimetric methods; HDL-c levels were obtained according to the principles established by Bucolo \& David (1973). The No-HDL cholesterol levels were obtained by the equation: No HDL-c $=$ TC - TG.

The animals of the groups DSS and DES received by oral gavage Simvastatim (20 mg), five days a week, for 8 weeks. The dosage were calculated by alometric extrapolation method, according to each animal metabolism and varied from 0.31 to $0.53 \mathrm{mg} / \mathrm{day}$, considering week readjust according to the weight gain of the animals.

The animals of exercised groups practiced physical exercise for eight weeks in a treadmill, using the exercise protocol described by Camargo Filho et al. (2005), which comprehended two phases: Adaptation (daily walking sessions with progressive duration during the ten first days of the experiment) and Training (daily 60 minutes of walking sessions, five days a week, for eight weeks) when the animals walked in a velocity of 9.75 meters per minute, totalizing 585 meters in each 60 minutes sessions.

After 72 hours of the last exercise session in the treadmill, the animals were sacrificed by decaptation and, after, the cardiac muscle was removed, frozen by immersion in $\mathrm{N}$-Hexana refreshed in nitrogen $\left(-70^{\circ} \mathrm{C}\right)$, using the frozen method for not fixed tissue (Dal Pai, 1995).

The laminas were done by histological cuts of $8 \mu \mathrm{m}$ and hematoxilin-eosin stain and used to the morphometric study of the myocardium fibers. This technique allows the evaluation of linear (shape coefficient and outline index) and tridimensional (volume, area and eccentricity) parameters of the nucleus using its relations to the major (DM) and minor (dm) diameters measurements.

For it, the laminae were observed in light microscope (H 500 Hund Wetzar®) using the immersion objective $(100 \mathrm{X})$; the nucleus of cardiac cell images were projected in a white millimeter paper and outlined with black pencil (number two), so obtaining the pictures to calculate the major and minor diameters.

The data analyses were done using descriptive statistics, with the values presented as mean and standard 
deviation. Student $\mathrm{T}$ test to paired data was applied to verify the differences in the lipid profile between the pre and post periods of the diet. The analyses of morphometric measures were done by the no-parametric test of KruskalWallis, being the differences pointed by the Dunn post hoc. All the results were presented by tables and graphics; for all analyses the significance level stipulated was $\mathrm{p}<0.05$. All the analyses were done using the statistic software SPSS 13.0 for Windows.

\section{RESULTS}

In the beginning of the research and after 30 days of hyperlipidic diet ingestion, blood samples were collected to the lipid profile analyses and dyslipidaemia verification in animals; the values are presented in Table I.

According to the results of paired $t$ test, there was a significant rise in total cholesterol and non-HDL cholesterol levels; there was also a significant reduction in HDL-cholesterol fractions, and the reduction of triglycerides was not significant.

The results of the morphometric analyses are presented as mean and standard deviation in Table II, and as graphics in Figs. 1 and 2.
According to the presented results, it was verified that for volume and area variables, the simvastatin sedentary group had the higher values, and the dyslipidemic exercise the lower ones, being the differences between groups statistically significant; the nuclear volume of the exercised with medication group was similar to the control group, not existing significant differences between them.

In the eccentricity variable, it was verified that the medicated sedentary group presented differences statistically significant between all the other groups, with its values lower than the other groups.

About shape coefficient and outline index, it was verified that both presented similar behaviors, where the medicated sedentary group had differences statistically significant between the other groups, being their values higher than the obtained for other studied groups.
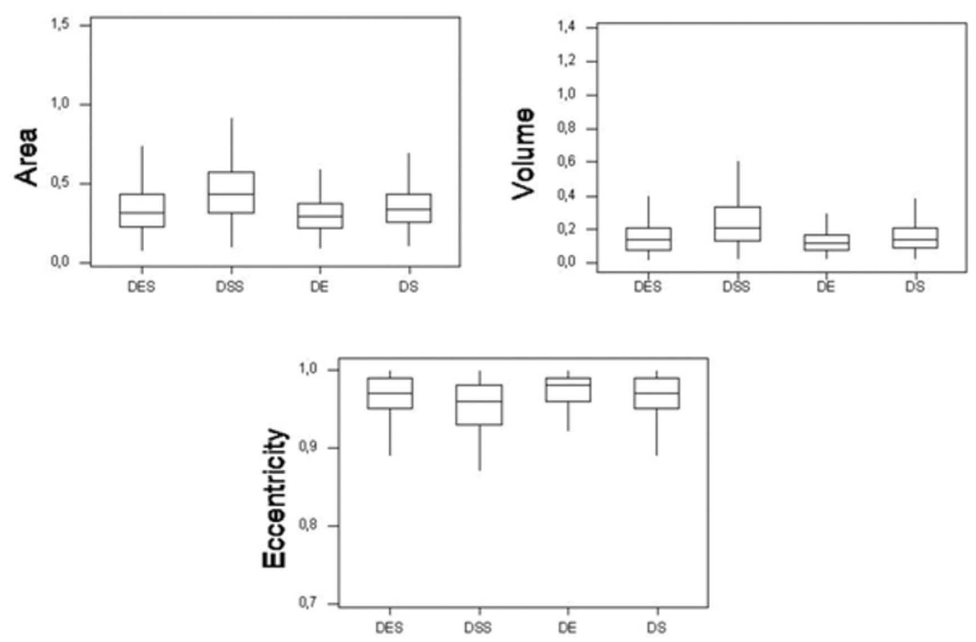

Fig. 1. Box-plot graphics of volume, area and eccentricity variables.

Table I. Values of the lipif profile (mean \pm standard deviation) and the difference between periods before (T0) and after (T1) diet.

\begin{tabular}{lccc}
\hline & T0 & T1 & p \\
\hline Total cholesterol & $95,92 \pm 34,82$ & $119,00 \pm 32,03$ & 0,004 \\
HDL - cholesterol & $30,42 \pm 8,60$ & $20,04 \pm 5,70$ & 0,000 \\
Non HDL - Cholesterol & $65,50 \pm 30,38$ & $98,96 \pm 30,44$ & 0,000 \\
Triglycerides & $103,19 \pm 43,42$ & $82,46 \pm 38,77$ & 0,092 \\
\hline
\end{tabular}

Table II. Values of morphometric variables (mean \pm standard deviation). (DS) dyslipidemic sedentary group; (DE) dyslipidemic exercise group; (DSS) dyslipidemic simvastatin sedentary group; (DSE) dyslipidemic simvastatin exercise group.

\begin{tabular}{lccccc}
\hline & Volume & Area & Eccentricity & Shape coefficient & Outline index \\
\hline DS & $0,17 \pm 0,14$ & $0,35 \pm 0,13$ & $0,97 \pm 0,02$ & $0,50 \pm 0,15$ & $5,25 \pm 0,98$ \\
DE & $0,13 \pm 0,08$ & $0,30 \pm 0,12$ & $0,97 \pm 0,02$ & $0,47 \pm 0,15$ & $5,39 \pm 1,00$ \\
DSS & $0,25 \pm 0,18$ & $0,46 \pm 0,21$ & $0,95 \pm 0,04$ & $0,58 \pm 0,17$ & $4,86 \pm 0,88$ \\
DSE & $0,16 \pm 0,11$ & $0,34 \pm 0,16$ & $0,97 \pm 0,03$ & $0,48 \pm 0,17$ & $5,46 \pm 1,21$ \\
\hline
\end{tabular}



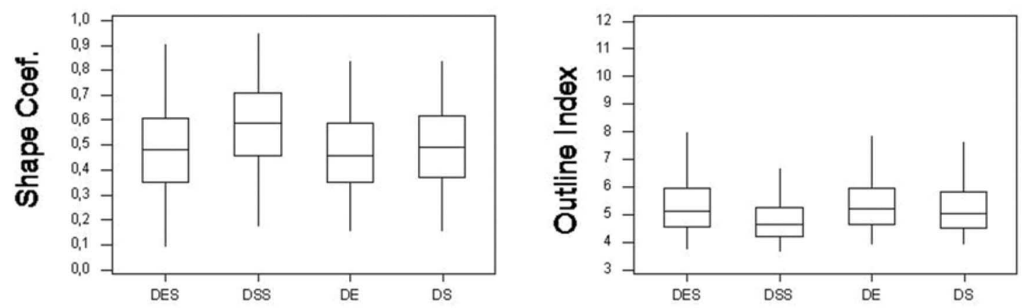

Fig. 2. Box-plot graphics of shape coefficient and outline index variables.

In summary, the medicated sedentary group presented differences statistically significant between all the other studied groups, in the tridimensional and linear variables, what explicits that this intervention per se promoted alterations in the cardiomyocytes.

\section{DISCUSSION}

The present reseach tried to verify the effects of statin administration and its interaction with aerobic physical activity in the morphometric parameters of the cardiac muscle of Wistar rats. It was verified that hyperlipidic diet was efficient in the induction of dyslipidemic state, what agree with other researches using rats (Cheik et al., 2006; Matos et al., 2005; Morais et al., 2003).

The morphometric results showed that medicated animals presented the highest values for nuclear volumes and areas. Moreover, these animals also presented altered values for shape coefficient and outline index, parameters elated to the nuclear shape.

Generally, statins act inhibiting the action of HMGCoA (hydroxymethylglutaryl-CoA) reductase enzyme, responsible for the conversion catalyzation of HMG-CoA into mevaonic acid reducing the production of intracellular and hepatic cholesterol. Besides the indirect effect of cardio protection caused by the lipid profile adequation, it has been reported the association of statin on the remodelation and regression of cardiac ventricular hypertrophy (Jasin'ska et $a l$.). In this case, statins would promote a cellular apoptosis state (cell death) what consequently produce the alteration described below.

This apoptosis induction of statins is related to its mechanism of action. The inhibition of HMG-CoA reductase is associated with a decreased in the production of various intermediary elements formed during the cholesterol syntheses process, such as the isoprenoids. These elements are responsible for the membrane proteins translocation and also for the syntheses of a component of the electrons transport chain (ubiquinone); these facts are the most probable cause of apoptosis induced by statins. That's because the diminution of ubiquinone in response to the statin therapy is associated with the rise of citosolic calcium, what active the caspases and the signaling cascade of apoptosis via mitochondria (Jasin'ska et al.).

Demyanets et al. (2006) verified that in adult human cardiac cells exposed in vitro to lipophilic statins, a proapoptotic state in the myocites was present, probably induced by the medication. Moreover, Rabkin \& Kong, (2003) verified that in cardiac cells submitted to lovastatin exposition in vitro, the cardiomyocites were more rounded and with citoplasmatic alterations; besides, nucleus were bigger, and some of them presented DNA disintegration and fragmentation.

In the present study it was verified that the cardiomyocites nucleus of the only medicated animals presented the highest values of area and volume, what agree with the findings of the above cited research, that is, bigger nucleus because of statin use. Moreover, there was also nuclear shape alterations, what suggests that these alterations can be related to the apoptosis occurrence as a consequence of satin use.

In addition to its benefic effects in the lipid profile adequation, the physical exercise also promote cardio protector effects, that are associated to the antioxidative enzymes and stress proteins (HSP72) adaptation (Starnes \& Taylor, 2007), besides the myocardial musculature hypertrophy.

When statin was taken together with the aerobic physical activity, it was verified that the cardiac morphometry values were similar to the control group. Although the exercise alone did not promote alteration in the cardiomyocites nucleus, what can be related to the effort intensity used, it can be suggested that when statin is taken together with exercise practice, the medication effects in the cardiac musculature are reduced. 
Considering that these statin effects are associated to apoptosis, the benefic association of medication and exercise can be explained based on Kavazis et al. (2007) search. The results of its search suggest that physical exercise promote biochemical alterations in the cardiac mitochondria resulting in a phenotype resistant to the apoptotic stimuli, reinforcing the concept of exercise cardio protector effect.
In summary, it can be suggested that statin use in the present study promoted cardiomyocites nucleus alterations that can be related to apoptosis occurrence. Moreover, when exercise was associated with statin intake, it was verified that statin effects were diminished, what can be related to the benefic adaptations of the cardiac musculature mitochondria in response to exercise, turning them more resistant to the apoptotic stimuli.

PADUlla, T. S. A.; AZOUBel, R.; BONFIM, R. M.; ACCIOLY, F. M.; CAMARGo FILHO, S. J. C.; PADOVANI, J. A.; BRANDÃO, A. C. \& SOUZA, S. D. R. Efectos de la asociación de estatina y del ejercicio aeróbico en los cardiomiocitos de ratón estudio morfométrico. Int. J. Morphol., 27(1):83-88, 2009.

RESUMEN: El ejercicio físico y las estatinas, intervenciones recomendadas para tratamiento de la dislipidemia, están independientemente relacionadas con las alteraciones de los cardiomiocitos, que se caracterizan por hipertrofia miocárdica y apoptosis, respectivamente. El objetivo del presente estudio fue analizar los efectos de la asociación de estatinas y el ejercicio físico aeróbico en los parámetros morfométricos del núcleo de células cardíacas. 40 ratas macho adultas se dividieron en cuatro grupos: ejercitadas (DE); sedentarias (DS), ejercitadas y con uso de estatina (DES), sedentarias y con uso de estatina (DSS). Los animales recibieron durante todo el período experimental una dieta hiperlipidemica añadiendo $20 \%$ de aceite de coco y 1,25\% de colesterol. Después de 30 días de su ingestión, se les extrajo sangre para verificar la dislipidemia. Los ejemplares ingirieron Simvastatina (20 mg) cinco días a la semana, durante ocho semanas. Durante este período, los animales ejercitaron 60 minutos diarios en la rueda de andar. Después del último día del protocolo,los animales fueron sacrificados y se les extrajo músculo cardiaco que fue mantenido en nitrógeno líquido $\left(-180^{\circ} \mathrm{C}\right)$. De este material se obtuvieron cortes que fueron teñidos por el método de hematoxilina-eosina y las fibras cardiacas fueron sometidas a análisis morfométrico nuclear. Los datos fueron analizados mediante el análisis descriptivo, prueba de la t de Student, prueba de Kruskal-Wallis y Dunn test post hoc. Para todos los análisis fue aprobado $\mathrm{p}<0,05$. Se comprobó que el grupo que recibió estatinas presentó valores estadísticamente significativos en comparación con los otros grupos, en las variables lineales y tridimensionales. En el grupo ejercitado y estatina, los valores obtenidos de los análisis morfométricos fueron similares a los del grupo control. Se sugiere que las estatinas, por sí solas, pueden causar alteraciones en el núcleo de las células cardiacas las cuales pueden estar relacionadas con la ocurrencia de apoptosis y, cuando se practica ejercicio asociado a la administración de estatina, los efectos de las estatinas pueden reducirse, pudiendo resultar beneficioso, en relación con las adaptaciones en la respuesta mitocondrial cardiaca al ejercicio físico, convirtiéndose en más resistentes a los estímulos de apoptosis.

PALABRAS CLAVE: Inhibidor hidroximetilglutaril CoA reductasa; Ejercicio; Núcleo de cardiomiocito.

\section{REFERENCES}

Accioly, M. F. Efeito do exercício físico e estatinas no perfil lipídico e na função muscular em ratos dislipidêmicos. São José do Rio Preto, Faculdade de Medicina de São José do Rio Preto, 2007.

Bucolo, G. \& David, H. Quantitative determination of serum triglycerides by the use of enzymes. Clin. Chem., 19(5):476-82, 1973.

Camargo Filho, J. C. S.; Vanderlei, L. C. M.; Camargo, R. C. T.; Oliveira, D. A. R.; Oliveira Junior, A. S, Dal Pai V. \& Belangero, W. D. Análise histológica, histoquímica e morfométrica do músculo sóleo de ratos submetidos a treinamento físico em esteira rolante. Arq. Ciênc. Saúde., 12(3):196-9, 2005.

Cambri, L. T.; Souza, M.; Mannrich, G.; Cruz, R. O. \& Gevaerd, M. S. Perfil lipídico, dislipidemias e exercícios físicos. Rev. Bras. Cineantropom. Desempenho Hum., 8(3):100-6, 2006.

Cheik, N. C.; Guerra, R. L. F.; Viana, F. P.; Rossi, E. A.; Carlos, I. Z.; Vendramini, R.; Duarte, A. C. G. O. \& Dâmaso, A. R. Efeito de diferentes frequiências de exercício físico na prevenção da dislipidemia e da obesidade em ratos normo e hipercolesterolêmicos. Rev. bras. Educ. Fís. Esp., São Paulo, 20(2):121-9, 2006.

Dal Pai, V. Histoenzimologia: Teoria e prática. Botucatu, Instituto de Biociências - Unesp, 1995.

Demyanets, S.; Kaun, C.; Pfaffenberger, S.; Hohensinner, P. J.; Rega, G.; Pammer, J.; Maurer, G.; Huber, K. \& Wojta, J. Hydroxymethylglutaryl-coenzyme A reductase inhibitors induce apoptosis in human cardiac myocytes in vitro. Biochem. Pharmacol., 71(9):1324-30, 2006. 
PADUlla, T. S. A.; AZOUbEL, R.; BONFIM, R. M.; ACCIOLY, F. M.; CAMARGO FILHO, S. J. C.; PADOVANI, J. A.; BRANDÃO, A. C. \& SOUZA, S. D. R. Effects of statin and aerobic physical exercise association in the cardiomyocites of the rat- morphometric study. Int. J. Morphol., 27(1):83-88, 2009.

Evangelista, F. S.; Brum, P. C. \& Krieger, J. E. Durationcontrolled swimming exercise training induces cardiac hypertrophy in mice. Braz. J. Med. Biol. Res., 36(12):1751-9, 2003.

Jasin'ska, M.; Owczarek, J, \& Orszulak-Michalak, D. Statins: a new insight into their mechanisms of action and consequent pleiotropic effects. Pharmacol. Rep., 59(5):483-99, 2007.

Kavazis, A. N.; McClung, J. M.; Hood, D. A. \& Powers, S. $\mathrm{K}$. Exercise induces a cardiac mitochondrial phenotype that resists apoptotic stimuli. Am. J. Physiol. Heart Circ. Physiol., 294:928-35, 2007.

Matos, S. L.; Paula, H.; Pedrosa, M. L.; Santos, R. C.; Oliveira, E. L.; Chianca Junior, D. A. \& Silva, M. E. Dietary models for inducing hypercholesterolemia in rats. Braz. arch. biol. technol., 48(2):203-9, 2005.

Morais, C. S. N.; Barcelos, M. F. P.; Sousa, R. V.; Lima, H. M. \& Lima, A. L. Efeitos das fontes e níveis de lipídios nas dietas de ratos machos da linhagem Wistar (Rattus norvegicus) sobre frações lipídicas do sangue. Ciênc. agrotec., 27(5):1082-18, 2003.

Prado, S. E. \& Dantas, E. H. M. Efeitos dos exercícios físicos aeróbio e de força nas lipoproteínas HDL, LDL e lipoproteína(a). Arq. Bras. Cardiol., 79(4):429-33, 2002.

Rabkin, S. W. \& Kong, J. Y. Lovastatin-induced cardiac toxicity involves both oncotic and apoptotic cell death with the apoptotic component blunted by both caspase2 and caspase-3 inhibitors. Toxicol. Appl. Pharmacol., 193(3):346-55, 2003.

Sociedade Brasileira de Cardiologia. IV Diretrizes brasileira sobre dislipidemias e prevenção da aterosclerose. Arq. Bras. Cardiol., 88(1):2-19, 2007.

Starnes, J. W. \& Taylor, R. P. Exercise-induced cardioprotection: endogenous mechanisms. Med. Sci. Sports Exerc., 39(9):1537-43, 2007.
Correspondence to:

Susimary Ap. Trevizan Padulla

FCT/Unesp - Physiotherapy Department

Roberto Simonsen Street No 305

CEP 19060-900

Presidente Prudente

São Paulo State

BRAZIL

Tel: (18) 3229-5388 - R.: 5365

Fax: (18) 3229-5353

Email: susi@fct.unesp.br

Received: 17-09-2008

Accepted: 22-11-2008 